\title{
Correction to: Unique numerical competence of Asian elephants on the relative numerosity judgment task
}

\author{
Naoko Irie ${ }^{1,2} \cdot$ Mariko Hiraiwa-Hasegawa $^{1}$. Nobuyuki Kutsukake ${ }^{1}$
}

Published online: 20 December 2019

(c) The Author(s) 2019

\section{Correction to: Journal of Ethology (2019) 37:111-115 https://doi.org/10.1007/s10164-018-0563-y}

The article Unique numerical competence of Asian elephants on the relative numerosity judgment task, written by Naoko Irie, Mariko Hiraiwa-Hasegawa and Nobuyuki Kutsukake, was originally published Online First without Open Access. After publication in volume 37, issue 1, page 111-115 the author decided to opt for Open Choice and to make the article an Open Access publication. Therefore, the copyright of the article has been changed to $($ The Author(s) 2019 and the article is forthwith distributed under the terms of the Creative Commons Attribution 4.0 International License (http://creativecommons.org/licenses/by/4.0/), which permits use, duplication, adaptation, distribution and reproduction in any medium or format, as long as you give appropriate credit to the original author(s) and the source, provide a link to the Creative Commons license, and indicate if changes were made.

The original article has been corrected.

Open Access This article is licensed under a Creative Commons Attribution 4.0 International License, which permits use, sharing, adaptation, distribution and reproduction in any medium or format, as long as you give appropriate credit to the original author(s) and the source, provide a link to the Creative Commons licence, and indicate if changes were made. The images or other third party material in this article are included in the article's Creative Commons licence, unless indicated otherwise in a credit line to the material. If material is not included in the article's Creative Commons licence and your intended use is not permitted by statutory regulation or exceeds the permitted use, you will need to obtain permission directly from the copyright holder. To view a copy of this licence, visit http://creativecommons.org/licenses/by/4.0/.

Publisher's Note Springer Nature remains neutral with regard to jurisdictional claims in published maps and institutional affiliations.

The original article can be found online at https://doi.org/10.1007/ s10164-018-0563-y.

Naoko Irie

aurotomame@gmail.com

1 Department of Evolutionary Studies of Biosystems, Sokendai (The Graduate University for Advanced Studies), Hayama, Miura, Kanagawa 240-0193, Japan

2 Japan Society for the Promotion of Science, Tokyo, Japan 